УДК 343.614

\title{
THE OFFENCE OF PERSUADING OR HELPING SOMEBODY TO COMMIT SUICIDE IN POLISH CRIMINAL LAW (ART. 151 OF THE CRIMINAL CODE)
}

\author{
M. Mozgawa \\ Maria Curie-Sklodowska University in Lublin, \\ Pl. M. Curie-Skłodowskiej 5, Lublin, Polska, 20-031, \\ e-mail:mmozgawa@poczta.umcs.lublin.pl
}

Suicide has been a grave social problem in Poland; in 2017 there have been 5276 lethal suicide attempts in the whole country. The number of initiated criminal proceedings referring to the offence from Art. $151 \mathrm{CC}$ is also substantial; in 2016 there were 3024 such cases, yet the number of confirmed offences was only a tiny fraction of the initiated proceedings (in 2016-11 such proceedings $(0.0036 \%)$. Only few of such cases are directed to courts; in the period from $1^{\text {st }}$ September 1998 (the date of entry into force of the Polish Criminal Code from $6^{\text {th }}$ June 1997) till the end of 2015 there have been, on the whole territory of Poland, only 23 valid convictions for the offence from Art. $151 \mathrm{CC}$. Art. $151 \mathrm{CC}$ criminalises causing another person to commit suicide by persuasion or assistance provision. The protected value is human life as well as the freedom from destructive influence on the way in which the victim disposes of his/her own life. The offence can be committed only by action in the case of causing the suicide attempt by persuasion, and in both forms of forbidden behaviour (action and omission) in the case of providing assistance in suicide. The offence is a material one; its features include the consequence understood not as the death of the victim but as the undertaking of the suicide attempt, no matter what its result was. It is a common offence which can be committed only intentionally (both types of intent are possible: dolus directus and dolus eventualis). The punishment for the offence is imprisonment from 3 months to 5 years.

Keywords: suicide, persuasion, providing assistance, suicide attempt.

DOI: http://dx.doi.org/10.30970/vla.2018.67.228

Suicide has been a serious social problem in Poland. As is shown by police statistics there were 5276 suicides which ended with death in Poland in 2017, in 2016 - 5 405, in 2014 6162 and in $2013-6101$. The number of initiated criminal proceedings referring to the offence from Art. 151 (causing a person to commit suicide by persuasion or providing assistance) is also significant. And thus, in 2016 there were 3024 such cases, in $2015-3193$, in $2014-3535$ and in $2013-3180$. Taking into account the importance of such a value as human life, in the majority of suicide cases criminal proceedings are initiated in order to verify the circumstances constituting the statutory features of the offence from Art. $151 \mathrm{CC}$ and make it clear whether the act of committing suicide was the result of a person's own decision or whether it took place as a result of persuasion or assistance of another person. The number of detected offences is a small fraction of the number of initiated proceedings (e.g. in 2016 - 11 proceedings $(0,0036 \%)$, in $2014-21(0,0059 \%)$, in $2013-15(0,0047)$. Only few of these cases are directed to courts; in the period between September 1, 1998 (the coming into force of the binding Criminal Code of June 6, 1997) until the end of 2015 there were only 23 valid convictions in Poland based on Art. 151 CC [19, p. 146].

As is commonly known contemporary criminal statues (the Polish one among them) do not consider suicide as a criminal act, no matter if the suicide attempt was successful 
or not $[4$, p. 372$]$. The question might be formulated about the lawmaker's motivation in criminalising the persuasion or assistance in suicide (especially in the context of the lack of criminality of committing or attempting to commit suicide). If one takes into account the general constructions of instigation and assistance referring to forbidden acts (described by Art. $18 \mathrm{CC}$ ), then there should be no doubts; these forms of committing offences are punished because of the blameworthiness of the perpetration of the act to which they lead $[15$, p. 26]. However, suicide is an act legally irrelevant, therefore it makes sense to ask why the lawmaker, having decided to leave suicide behaviour outside of criminalisation, does not do the same in reference to the persons cooperating with the self-killer in the act of auto-destruction. It can be, as it seems, assumed (with much simplification) that the interdiction to persuade or assist in suicide has most of all the aim to prevent abuses, i.e. such cases in which the person cooperating in the suicide of another person does so for blameworthy reasons (e.g. to harm the victim or event profit from his/her death) [15, p. 27$]$. There is no doubt that Polish criminal law does not criminalise suicide and there have been no positive results of the attempts to find other bases for the responsibility of the self-killer who survived the suicide attempt [e.g. Art. $13 \S 1 \mathrm{CC}$ in connection with Art. $148 \S 1 \mathrm{CC}$ (attempt to commit murder), Art. $156 \mathrm{CC}$ (serious bodily harm), Art. $157 \mathrm{CC}$ (medium or minor bodily harm) or Art. $160 \mathrm{CC}$ (bringing the danger of losing life or suffering a serious bodily harm), of course assuming that the self-killer did not infringe on the values of other persons [2, p. 130 et al.]. The above does not mean that in every case (regardless of the circumstances, the method chosen by the self-killer and the caused results) the act of the self-killer will not cause criminal responsibility. There are a number of offences which can be attributed to the unsuccessful self-killer in connection with the suicide attempt (e.g. unintentional causing of the death of a person by the unsuccessful self-killer jumping from a roof or causing a road accident - Art. 177 CC). Such a solution is necessary since otherwise the unsuccessful self-killer would be getting immunity from prosecution for committed acts which could even lead to simulated suicide attempts whose real aim would be to harm another person.

It is usually accepted that the value protected by Art. $151 \mathrm{CC}$ is human life [10, p. $906 ; 27$, p. $865 ; 1$, p. $147 ; 22$, p.410; 5, p.145]. It is sometimes explained that the protection refers to life as a social value, i.e. the value that cannot be freely disposed of by its holder [29, p. 320; 18, p. 306]. Such an approach is being criticised, however, and its opponents claim that the fact that man does not have the right to freely dispose of his own life, since it is protected regardless of his will, should not mean that his freedom is excluded to such an extent that also the right to undertake auto-destructive acts is excluded [8, p. 193; 15, p. 26 et al.]. The opinion expressed by J. Giezek seems to be convincing - according to him the protected value of Art. $151 \mathrm{CC}$ is first of all human life, but it is also the freedom from destructive influences on the way in which a person disposes of his own life [8, p. 193].

Art. 151 describes the forbidden act as «causing a man to attack his own life» and this can be done either by persuasion or by providing assistance. The question appearing here is whether the terms persuasion and providing assistance have the same range as instigation and abetting in crime defined in Art. $18 \S 2$ and $3 \mathrm{CC}$. The dominating opinion is that to interpret these terms the provisions referring to the above mentioned forms of cooperation in crime should be applied [13, p.48]. Such an opinion is expressed, among others, by A. Zoll [29, p. 320-321], B. Michalski [18, p. 306], M. Królikowski [14, p. 278].

Special attention should be paid to the way of understanding the terms «persuasion» and "providing assistance» as the features of the analysed offence by the criminal law doctrine. Let us start with the term persuasion which leads to more difficulties, as it 
seems. According to A. Marek «persuading somebody to commit suicide means inducing which constitutes the content of the actus reus of instigation» [16, p. 378], the same opinion is expressed by A. Wassek [26, p. 60]. A different opinion is presented by K. Daszkiewicz who maintains that Art. $151 \mathrm{CC}$ (as well as the earlier expressions of that provision) has not introduced instigation but only persuasion and - according to this Author, «these are not the same» [6, p. 250]. In L. Tyszkiewicz's opinion «instigation has been described by the feature «incitation» instead of «persuasion» which means that the scope of forms of instigation has been limited to those that are less intense» [24, p. 943]. P. Góralski also thinks that persuasion to commit suicide is a term with stricter meaning if compared to instigation [9, p. 39]. One should share the opinion of those doctrine representatives who accept the identical meaning of persuasion and incitement, and the use of the term persuasion instead of incitement should be justified through linguistic reasons $[13$, p.50]. According to the Dictionary of the Polish Language, to persuade means «to encourage somebody to something, to incite, to convince», therefore there are no rational arguments to ascribe to it some meaning other that the one suggested by the grammatical interpretation (http://sjp.pl/namawia\%C4\%87).

Generally speaking, persuasion means influencing the intellectual, as well as emotional sphere of another person which is to result in the intention to commit suicide $[13$, p. 50]. Approving the identity the of meaning range of persuasion and incitement I express the opinion that persuasion has a broad meaning range which includes not only verbal forms but also all other forms (written, text messages, e-mails and even obvious gestures) as long as they are capable of influencing the will of a person so effectively as to lead to the appearance of the auto-destruction intent. Though there may be some doubts about treating gestures as belonging to the category of persuasion, yet there seem to be no justified grounds for rejecting them (e.g. unambiguous signs persuading somebody to commit suicide made by a death-mute person, gestures addressed to the victim through a glass window or from such a distance from which the voice could not be heard or with accompanying noise). Such gestures (e.g. encouraging a hesitating person to jump from a high building) may, of course, be sometimes treated as assistance in suicide in the meaning of Art. $151 \mathrm{CC}$ (since the intent to attack one's own life has already been there).

The persuading person needs not have direct contact with the persuaded one; any form of distant communication is possible: a telephone call, a conversation through the Internet (e.g. skype), written correspondence (letters, text messages, e-mails) [10, p. 909; 1, p. 148]. The self-killer needs not know the person who is persuading or assisting him in the commission of the suicide; the offender may remain unknown for the victim (e.g. providing information through the Internet). Both persuasion and assistance in suicide must refer to a specified person, even if these persons are quite numerous (e.g. members of a numerous sect who receive the persuasion from their guru) [10, p. 910].

One cannot treat as persuasion the agitating to commit suicide which is not directed at a specific person, yet, the opinion is sometimes stressed in the literature that it is possible to treat as persuasion an expression inciting somebody to commit suicide placed in a commentary in a blog or a social networking service [1, p. 148]. However, one cannot treat as persuasion or assistance in suicide the creation and publication of instruction materials, advice and guidelines how to commit suicide, as well as other materials which hypothetically might facilitate committing suicide, if they are addressed to an unspecified, anonymous range of recipients $[7$, p. 335; 9, p. 42]. The statutory features of the offence from Art. $151 \mathrm{CC}$ will also not be fulfilled if one publicly calls for committing suicide (if it does not refer to a specified person) $[7$, p. 335; 9, p. 42]. As is pointed out in literature, in 
such a case it is not possible either to consider the statutory features of the offence from Art. $255 \mathrm{CC}$ (public calling for the commission of an offence or approving it) to be fulfilled since there is no illegality of the act the offender was referring to [10, p. 910].

Persuasion needs to be clear and unambiguous and its content may lead to no doubts about the offender's intention. If the offender's behaviour takes on the form of stalking or maltreatment which leads to the victim's suicide attempt, one should consider the responsibility based on Art. 190a $\S 3$ CC or $207 \S 3$ CC (possibly also Art. $352 \S 3$ CC).

Persuasion as defined in Art. $151 \mathrm{CC}$ may have the shape of a plea, suggestion, proposition etc. Applying threat, blackmail, enforcement or hypnosis - in R. Kokot's opinion - goes beyond the scope of that feature [10, p. 909]. In such cases it seems justified to consider the legal qualification based on Art. $148 \S 1$ or $2 \mathrm{CC}$ (the basic or aggravated type of murder). One should pay special attention to the opinion of A. Wasek, who claimed that the offender who participated in a joint suicide only in order to get rid of the victim be means of his/her own behaviour should nonetheless be held responsible only on the basis of Art. 150 (euthanasia killing) or $151 \mathrm{CC}$, and not of Art. $148 \mathrm{CC}$. According to that Author, the offender's deceit should be taken into account at the stage of punishment imposition [26, p. 109]. There may be some doubts about this solution. The qualification based on Art. $151 \mathrm{CC}$ in such a case does not seem right, the more so because it could thus be treated as a sort of «bonus» for the offender's ingenuity. What is more, there may be cases in which the offender applying deceit will do it for reasons deserving special condemnation which should lead to the use of the qualification based on Art. $148 \S 2$ point $3 \mathrm{CC}$. If the use of violence is considered in turn, P. Góralski seems to be right when he claims that it would be going too far to maintain that Art. $151 \mathrm{CC}$ is the proper one in the cases in which the offender used violence to make the victim commit suicide. Though the interpretation of the term «cause» does not exclude it, yet it is doubtful, taking into consideration the meaning of the words «assist» and «persuade», whether such acts can be performed by the use of violence against the potential self-killer $[9$, p. 43]. This Author does not state what the proper qualification in such cases should be (though it seems that it should be Art. $148 \mathrm{CC}$ ).

If the victim's intention to commit suicide was not caused by the persuasion of the offender and materialised for other reasons, and the offender by his persuasion only strengthens that intention in the psyche of the potential self-killer (e.g. be giving him advice, tips, information, removing some doubts), then the behaviour of the offender should not be treated as persuasion (in the meaning of Art. $151 \mathrm{CC}$ ), but as psychical assistance (which fulfils the second of the verb features of the offence from Art. $151 \mathrm{CC}$ ) [18, p. 307-308].

There are diversified opinions referring to the assessment of the strengthening of the victim's intention to commit suicide. Some authors claim that it can be treated as persuasion, especially in those cases in which the potential self-killer was hesitating whether to commit the act of self-destruction (A. Wassek [26, p. 61], M. Budyn-Kulik [1, p. 148], J. Giezek [8, p. 194]). A similar interpretation may also be found in some decisions of the Supreme Court (compare e.g. the sentence of the Supreme Court from January 24, 1967, II KR 211/66, unpublished). Yet, such an interpretation is not justified. The strengthening of the potential self-killer's decision should be treated not as persuasion but as psychic assistance in committing suicide [13, p. 51]. This solution dominates among the criminal law authors (among others: M. Cieślak [4, p. 378], B. Michalski [18, p. 307-308], A. Marek [16, p. 378]). According to R. Kokot in such a situation one should consider applying the construction of impossible attempt (Art. $13 \S 2 \mathrm{CC}$ ), when the offender did not know about the already taken suicide intent [11, p. 25]. 
Assisting somebody in suicide, as a rule (though obviously taking into account the specificity of a suicide act) corresponds with the formula of abetting described in Art. 18 $\S 3 \mathrm{CC}[11$, p. 29], therefore it may be manifested both by action and omission in the case in which the offender does not fulfil a specific legal obligation to prevent a suicide attempt [9, p. 277; 10, p. 909]. The offender plays then the role of a guarantor who is burdened with the specific legal obligation to prevent a consequence in the form of another person's suicide attempt [8, p. 194]. As is rightly pointed out by K. Burdziak, Art. $151 \mathrm{CC}$ speaks of providing assistance and not about facilitating, as does Art. $18 \S 3$ $\mathrm{CC}[3$, p. 181]. According to that Author, though the analysed expression should be characterised in a way similar to abetting, yet it should be stressed that the provided assistance must cause the suicide attempt of another person (so it must cause, in an indirect way, the undertaking of a suicide attempt) [3, p. 182].

It does not matter for the legal qualification whether providing assistance was inspired by the victim or was the offender's own initiative (though this may undoubtedly influence the imposition of punishment) [12, p. 29].

Unlike persuasion which always precedes the intention to commit suicide (and is intellectual), assistance (as a rule, though not always) is of physical nature and may be provided to a person who has already formed the intention to commit suicide [21, p. 57]. The core of assistance lies in facilitating another person the execution of the suicide intention (e.g. by providing a gun, poison, as well as providing advice, tips or strengthening the already taken suicide intention) [17, p. 69]. Psychic assistance shouldaccording to the interpretation adopted by the Supreme Court - be understood as «first of all verbal assistance in contrast to assistance by action. This type of assistance may take on the shape not only of giving advice and tips which are to facilitate the suicide but also of such a behaviour of the offender which in a extremely suggestive way manifests his solidarity with the intent of the self-killer and may, in some cases, create the atmosphere in which the intention of the self-killer is forming, maturing and it strengthens the already taken intention (...)» $\{$ Sentence of the Supreme Court of August 9, 1973, I KR 178/73, Orzecznictwo Sadu Najwyższego Izba Karna i Wojskowa 1974, issue 3, position 43.\}.

It should be stressed that not every persuasion and not every assistance in suicide will lead to the fulfilment of the statutory features of the offence from Art. $151 \mathrm{CC}$. According to the disposition of that provision the actus reus will be achieved only by acts «which exert so intense an influence on another person that they may be considered to be meeting the requirements of $<<$ causing $>>$ the suicide attempt $[11$, p. 23]. According to the linguistic meaning, «to cause» means «to become the cause of something, lead somebody to something, to trigger out something» [1, p. 149]. There is no doubt that not every persuasion and not ever assistance will fulfil the statutory features of the analysed offence, but only such which can be called "persuasion causing the suicide attempt» or «assistance causing the suicide attempt». As is emphasised in literature, the offender's behaviour in the causal sense must be the necessary condition for the suicide attempt in such a way that it can be stated that without the persuasion or assistance there would have been no suicide attempt; the attribution of the consequence will be possible only if the offender's behaviour was of crucial and decisive meaning in that respect [11, p. 23].

The offence from Art. 151 is a material one. Its features comprise the consequence understood however as the undertaking of the suicide attempt, no matter what its outcome, and not as the death of a person [1, p. 150; 17, p. 69]. The actus reus is therefore completed not only when the value of life has been destroyed, but also when it has been endangered in the case of an unsuccessful suicide attempt (when the attempt only lead to the direct danger of losing life) [11, p. 24]. Obviously, the responsibility for 
attempting to commit the offence from Art. 151 CC may be applied on regular basis. This will be the case when the persuasion will not invoke the victim's intention to kill himself at all, as well as when the intention was formed but the victim's actions did not go as far as making an attempt to kill himself [17, p. 69]. The attempt may be as well possible as impossible, and - what seems clear - the impossibility must lie on the offender's side (i.e. the person causing another's suicide attempt) and does not refer to the impossibility on the victim's side. Therefore an impossible attempt will take place when the offender uses a language the victim does not speak or when the offender gives the future self-killer, in order to make it possible for him to get poisoned, some substance which is not poisonous [11, p. 25].

The object of the executive act is the source of many interpretation problems in the case of the offence from Art $151 \mathrm{CC}$. It is assumed that it may only be a person who is capable to make an autonomous decision (in the case of persuasion) or a person who has already made such a decision consciously (in the case of providing assistance). It is often assumed in the literature that a person who, because of his age or mental state (e.g. a minor or an insane person), is not able to recognise the meaning of his act or to direct his act, cannot be the object of the offender's action (in such cases the qualification based on Art. 148 should be applied) [1, p. 150].

The offence described in Art. $151 \mathrm{CC}$ is a common one. When it is committed by action, anyone can be its perpetrator, while the omission fulfilling the statutory features of that offence may only be committed by the person who is burdened with a special legal obligation to prevent the consequence (Art. $2 \mathrm{CC}$ ); in this respect the offence is individual.

The statutory features of the offence from Art. $151 \mathrm{CC}$ may be fulfilled not only in the form of single-handed perpetration but also co-perpetration (and of course, multiperpetration). There are some doubts about the possibility of committing this offence through the non-executive forms of perpetration (directing and ordering). The general rules on responsibility apply to the form of instigation and abetting. Therefore, instigation to persuasion to commit suicide, as well as instigation to provide assistance or abetting referring to both persuasion and providing assistance in suicide attempt are possible.

There seems to dominate in the literature the opinion that the offence from Art. 151 $\mathrm{CC}$ in the form of persuasion may only be committed with the direct intent, while in the form of providing assistance both dolus directus and dolus eventualis are possible [23, p. $356 ; 4$, p. $378 ; 28$, p. $448 ; 1$, p. $151 ; 29$, p. $323 ; 16$, p. $378 ; 14$, p. 280; 10, p. 911]. Some doubts have been, however, expressed referring to the possibility of accepting the dolus eventualis in the case of persuading somebody to commit suicide. According to A. Wąsek the term «persuasion» (just like the term «inciting») does not encode the aim of the offender's action. Therefore, if instigation was by its nature limited to the direct intent, then it would be unnecessary to statutorily limit the subjective side of instigation (Art. $18 \S 2$ CC) to the direct intent [26, p. 62]. Had the lawmaker not accepted the possibility of inciting with eventual intent, then limiting the range of criminalisation to the direct intent would not have been justified. This makes it possible to draw the conclusion that the term persuasion (corresponding with inciting) also does not give grounds for performing the interpretation limiting the possibility of committing the offence from Art. 151 (in the form of persuasion) only to the direct intent. The arguments presented by A. Wassek are convincing. Undoubtedly the term ,persuasion» does not have any intentional colouring and it is not difficult to imagine such examples of persuasion when the offender wants another person to form a given intention and such when he only accepts such a result of his persuading. The just opinion of A. Wasek is shared by J. Kosonoga-Zygmunt [13, p. 52] and - as it seems - P. Góralski [9, p. 40]. 
No motive or purpose belongs to the statutory features of the offence defined in Art. 151 $\mathrm{CC}$. However the seriousness of the offence is largely dependent on the fact whether the offender was acting out of noble or evil motivation [26, p. 63]. Interesting issues can be associated with the situation in which the offender causes the victim to commit suicide by providing assistance in response to the victim's request and if he was feeling compassion. There are three attitudes referring to that problem: $1 /$ according to some criminal law authors the offender's act is not punishable (it is legally invalid, which is supported by the interpretation of the provisions of Art. 151 and $150 \S 2$ CC) [20, p. 97], 2/ according to other authors, assistance in suicide provided on the victim's request and under the influence of compassion is de facto an euthanasia killing and as such should be prosecuted on the basis of Art. $150 \mathrm{CC}[6$, p. 236], 3/ the third group of authors claims that even in the case when request and compassion are present on the offender's side the right qualification is the one referring to Art. $151 \mathrm{CC}[25$, p. $76 ; 9$, p. 45]. The last of these opinions should be shared. The right qualification in such a case is the one from Art. $151 \mathrm{CC}$, while the presence of request and compassion will constitute circumstances influencing the punishment (and may lead to the extraordinary mitigation of punishment) [26, p. 63]. Unintentional causing the suicide attempt of another person does not fulfil the statutory features of the offence from Art. 151 $\mathrm{CC}$; yet Art. $155 \mathrm{CC}$ (unintentional killing of a person) may be considered.

6. The offence form Art. $151 \mathrm{CC}$ is punished with imprisonment from 3 months to 5 years. If the imposed punishment does not exceed 1 year, then its execution may be conditionally suspended. It is possible to apply the provision of Art. 37a $\mathrm{CC}$ (,If the statutory punishment does not exceed 8 years of imprisonment, the court may impose, instead of that punishment, the punishment of fine or the punishment of restriction of liberty described in Art. 34 \& 1 a point 1,2 or 4»), as well as to impose the so called mixed punishment (Art. 37b CC: "In the case of a misdemeanour punished with imprisonment, regardless of the minimum punishment for a given offence, the court may jointly impose imprisonment not exceeding 3 months, and if the maximum punishment is no less than 10 years - 6 months and the punishment of restriction of liberty up to 2 years. The provisions of Art. 69-75 do not apply. The punishment of imprisonment is to be executed first, unless the statute provides otherwise»). It is also possible to apply to the perpetrator of Art. $151 \mathrm{CC}$ the conditional discontinuance of criminal proceedings, of course, when the conditions from Art. $66 \S 1 \mathrm{CC}$ are met. Condemnation for the offence from Art. 151 $\mathrm{CC}$ may be accompanied by the following criminal measures: deprivation of public rights (if the offender is punished with no less then three years of imprisonment for an offence committed with especially blameworthy motivation), interdiction to occupy a certain position or performe a profession (Art. $41 \S 1 \mathrm{CC}$ ), making the sentence publicly known (Art. $50 \mathrm{CC}$ ). It is also possible to impose on the perpetrator the obligation to make reparation for the damage caused or the injury sustained (Art. $46 \mathrm{CC}$ ), exemplary damages (Art. $47 \S 1 \mathrm{CC}$ ) and sometimes to impose the forfeiture of objects (Art. $44 \mathrm{CC}$ ).

Empirical research referring to the offence from Art. $151 \mathrm{CC}$ in Poland in the years 1998-2015, conducted by M. Mozgawa and P. Bachmat, show that the typical offender is a man under 40 (72,2\% of all accused), poorly educated $(61,1 \%$ have only basic professional education), living in a town, in half of the cases - punished earlier, most were single $(61,1 \%)$, childless $(55,6 \%)$, in half of the cases pleading guilty. The typical victim is a young person (59,9\% under the age of 25$)$, a woman (63,3\%), usually closely related to the offender $(59,9 \%)$. Persuasion, as a rule, took on the form expressed only verbally, while the providing of assistance usually took the form of providing the victim the measures which are to facilitate the commission of suicide. The preferred ways of depriving oneself of life were those which did not require any special measures 
for their execution (most of all hanging oneself). A quarter of the analysed cases had the background of family violence and the fulfilment of the statutory features of the offence from Art. $151 \mathrm{CC}$ was mingled with maltreatment (Art. 207 CC) [19, p. 151 et al.].

\section{Список використаних джерел}

1. Budyn-Kulik M. [w:] J. Warylewski (red.) System Prawa Karnego, vol. 10. Przestępstwa przeciwko dobrom indywidualny. Warszawa, 2016.

2. Burdziak K. Samobójca czy zabójca? Kilka słów na temat statusu samobójcy w polskim prawie karnym // Wojskowy Przegląd Prawniczy. 2014, nr 4.

3. Burdziak $K$. Kierowanie wykonaniem samobojstwa i polecenie jego wykonania w polskim prawie karnym // Ruch Prawniczy, Ekonomiczny I Socjologiczny, 2014, nr 4.

4. Cieślak M. [w:] I. Andrejew, L. Kubicki, J. Waszczyński (red.), System Prawa Karnego, O przestępstwach w szczególności, vol. IV, part 1, Ossolineum 1985.

5. Ć́wiklicz U. K. Eutanazja a wspomagane samobójstwo // Przegląd Policyjny. 2009. No 3.

6. Daszkiewicz K. Przestępstwa przeciwko życiu i zdrowiu, Komentarz. Warszawa 2000.

7. Filar M. Lekarskie prawo karne. Kraków, 2000.

8. Giezek J. [w:] J. Giezek (red.). Kodeks karny. Część szczególna. Warszawa, 2014.

9. Góralski P. Pomoc i namowa do samobójstwa (art. 151 k.k.) // L. Bogunia (red.), Nowa kodyfikacje prawa karnego, vol. XIII, Wrocław, 2003.

10. Kokot R. [w:] R.A.Stefański (red.), Kodeks karny. Komentarz. Warszawa, 2015.

11. Kokot $R$. Z problematyki karalnego doprowadzenia do samobójstwa - uwagi na tle ustawowych znamion art. 151 k.k., cz. I, Nowa Kodyfikacja Prawa Karnego, vol. XXXV. Wrocław, 2015.

12. Kokot $R$. Z problematyki karalnego doprowadzenia do samobójstwa - uwagi na tle ustawowych znamion art. 151 k.k., cz. II, Nowa Kodyfikacja Prawa Karnego, vol. XXXVI. Wrocław, 2015.

13. Kosonoga-Zygmunt $J$. Namowa i udzielenie pomocy do samobójstwa (art. 151 k.k.) // Prokuratura i Prawo. 2015. nr 11.

14. Królikowski M. [w:] M. Królikowski, R. Zawłocki (red.). Kodeks karny. Część szczególna, vol. I. Warszawa, 2017.

15. Malczewski J. Problemy z prawną kwalifikacją lekarskiej pomocy do samobójstwa (art. 151 k.k.) // Prokuratura i Prawo. 2008. nr 11.

16. Marek A. Kodeks karny. Komentarz. Warszawa, 2010.

17. Mazurek A. Odpowiedzialność karna za podżeganie lub pomoc do samobójstwa oraz doprowadzenie do zamachu samobójczego // Wojskowy Przegląd Prawniczy. 1980. nr 1.

18. Michalski B. [w:] A. Wąsek, R.Zawłocki (red.) Kodeks karny. Część szczególna, t. I, Komentarz do art. 117-221. Warszawa, 2010.

19. Mozgawa M., Bachmat P. Namawianie lub udzielenie pomocy do samobójstwa (art. 151 k.k.) w świetle badań empirycznych // M. Mozgawa (red.), Samobójstwo. Warszawa, 2017.

20. Poklewski-Koziett K. Postrzeganie eutanazji prawnicze - medyczne - etyczne // Państwo i Prawo. 1998. nr 12.

21. Popławski H. Doprowadzenie do samobójstwa // Patologia Społeczna-Zapobieganie. T. X. 1981.

22. Szwarczyk M. [w:] T. Bojarski (red.). Kodeks karny. Komentarz. Warszawa, 2016.

23. Śliwowski J. Prawo karne. Warszawa, 1979.

24. Tyszkiewicz L. (w:) M. Filar (ed.). Kodeks karny. Komentarz. Warszawa, 2016.

25. Warylewski J. W sprawie karnoprawnego postrzegania eutanazji // Państwo i Prawo. 1999. nr 3.

26. Wasek A. Prawnokarna problematyka samobójstwa. Warszawa, 1982.

27. Wiak K. [w:] A Grześkowiak, K. Wiak (red.). Kodeks karny. Komentarz. Warszawa, 2015.

28. Wolter $W$. [w:] I. Andrejew, W. Świda, W. Wolter. Kodeks karny z komentarzem. Warszawa, 1973.

29. Zoll A. [w:] A. Zoll (red.), Kodeks karny. Część szczególna, Tom II, Komentarz do art. 117211a. Warszawa, 2017. 


\section{References}

1. Budyn-Kulik, M. (2016). [in:] J. Warylewski (ed.) System Prawa Karnego, vol. 10. Przestępstwa przeciwko dobrom indywidualnym, Warszawa.

2. Burdziak, K. (2014). Samobójca czy zabójca? Kilka słów na temat statusu samobójcy w polskim prawie karnym. Wojskowy Przeglad Prawniczy, No 4.

3. Burdziak, K. (2014). Kierowanie wykonaniem samobojstwa i polecenie jego wykonania w polskim prawie karnym. Ruch Prawniczy, Ekonomiczny i Socjologiczny, № 4.

4. Cieślak, M. (1985). [in:] I. Andrejew, L. Kubicki, J. Waszczyński (eds.), System Prawa Karnego, O przestęsstwach w szczególności, vol. IV, part 1, Ossolineum.

5. Ćwiklicz, U. K. (2009). Eutanazja a wspomagane samobójstwo. Przeglad Policyjny, No 3.

6. Daszkiewicz, K. (2000). Przestęstwa przeciwko życiu i zdrowiu, Komentarz. Warszawa.

7. Filar, M. (2000). Lekarskie prawo karne, Kraków.

8. Giezek, J. (2014). [in:] J. Giezek (ed.). Kodeks karny. Część szczególna, Warszawa.

9. Góralski, P. (2003). Pomoc i namowa do samobójstwa (art. 151 k.k.) [in:] L. Bogunia (ed.). Nowa kodyfikacje prawa karnego, vol. XIII, Wrocław.

10. Kokot, R. (2015). [in:] R. A. Stefański (ed.). Kodeks karny. Komentarz. Warszawa.

11. Kokot, R. (2015). Z problematyki karalnego doprowadzenia do samobójstwa - uwagi na tle ustawowych znamion art. 151 k.k., cz. I, Nowa Kodyfikacja Prawa Karnego, vol. XXXV, Wrocław.

12. Kokot, R. (2015). Z problematyki karalnego doprowadzenia do samobójstwa - uwagi na tle ustawowych znamion art. 151 k.k., cz. II, Nowa Kodyfikacja Prawa Karnego, vol. XXXVI, Wrocław.

13. Kosonoga-Zygmunt, J. (2015). Namowa i udzielenie pomocy do samobójstwa (art. 151 k.k.). Prokuratura i Prawo, No 11.

14. Królikowski, M. (2017) [in:] M. Królikowski, R. Zawłocki (red.). Kodeks karny. Część szczególna, vol. I, Warszawa.

15. Malczewski, J. (2008). Problemy z prawną kwalifikacją lekarskiej pomocy do samobójstwa (art. 151 k.k.). Prokuratura i Prawo, No 11.

16. Marek, A. (2010). Kodeks karny. Komentarz, Warszawa.

17. Mazurek, A. (1980). Odpowiedzialność karna za podżeganie lub pomoc do samobójstwa oraz doprowadzenie do zamachu samobójczego. Wojskowy Przeglą Prawniczy, no 1.

18. Michalski, B. [in:] A. Wąsek, R. Zawłocki (eds.) Kodeks karny. Czesść szczególna, t. I, Komentarz do art. 117-221, Warszawa.

19. Mozgawa, Bachmat, P. (2017). Namawianie lub udzielenie pomocy do samobójstwa (art. 151 k.k.) w świetle badań empirycznych, [in:] M. Mozgawa (ed.), Samobójstwo, Warszawa.

20. Poklewski-Koziełł, K. (1998). Postrzeganie eutanazji prawnicze - medyczne - etyczne. Państwo i Prawo, No 12.

21. Popławski, H. (1981). Doprowadzenie do samobójstwa. Patologia Społeczna-Zapobieganie, t. X.

22. Szwarczyk, M. (2016). [in:] T. Bojarski (ed.), Kodeks karny. Komentarz, Warszawa.

23. Śliwowski, J. (1979). Prawo karne, Warszawa.

24. Tyszkiewicz, L. (2016). (w:) M. Filar (ed.), Kodeks karny. Komentarz, Warszawa.

25. Warylewski, J. (1999). W sprawie karnoprawnego postrzegania eutanazji. Państwo i Prawo, No 3.

26. Wąsek, A. (1982). Prawnokarna problematyka samobójstwa, Warszawa.

27. Wiak, K. (2015). [in:] A. Grześkowiak, K. Wiak (eds.), Kodeks karny. Komentarz, Warszawa.

28. Wolter, W. (1973). [in:] I. Andrejew, W. Świda, W. Wolter, Kodeks karny z komentarzem, Warszawa.

29. Zoll, A. (2017). [in:] A. Zoll (ed.), Kodeks karny. Część szczególna, vol. II, Komentarz do art. 117-211a, Warszawa. 


\title{
ЗЛОЧИН ПЕРЕКОНУВАННЯ АБО СПРИЯННЯ ВЧИНЕННЮ САМОГУБСТВА В ПОЛЬСЬКОМУ КРИМІНАЛЬНОМУ ПРАВІ (СТ. 151 КРИМІНАЛЬНОГО КОДЕКСУ)
}

\author{
М. Мозгава \\ Університет Марії Кюрі-Склодовської, \\ пл. М. Кюрі-Склодовської, 5, Люблін, Республіка Польща, 20-031, \\ e-mail:mmozgawa@poczta.umcs.lublin.pl
}

Самогубство $є$ серйозною соціальною проблемою в Польщі. Відповідно до статистики, в 2017 р. по всій країні було вчинено 5276 спроб самогубства із летальними наслідками, в 2016 р. - 5 405, в 2014 - 6 162, а в 2013 р. - 6 101. Кількість порушених кримінальних проваджень стосовно злочину, передбаченого ст. 151 Кримінального кодексу Республіки Польща (доведення іншої особи до самогубства шляхом переконування або надання допомоги), є також значною. Так, в 2016 р. було порушено 3024 такі провадження, в 2015 3 193, в 2014 - 3 535, а в 2013 - 3 180. Проте кількість підтверджених злочинів становила лише невелику частку від порушених проваджень (наприклад, у 2016 р. - лише 11 зі загальної кількості таких проваджень (0,0036 \%), у 2014 р. - 21 (0,0059\%), у 2013 р. - 15 $(0,0047$ \%). Лише невелику кількість таких справ скеровуютьдо судів; у період з 1 вересня 1998 р. (дата набуття чинності Кримінального кодексу Польщі від 6 червня 1997 р.) до кінця 2015 р. по всій території Польщі було лише 23 засудження за злочин, передбачений ст. 151 Кримінального кодексу РП.

Загальновідомо, що сучасні кримінальні кодекси (у тому числі польський КК) не передбачають самогубство як злочин, незалежно від того, чи спроба самогубства була успішною, чи ні. Ст. 151 КК РП встановлює кримінальну відповідальність за доведення іншої особи до самогубства шляхом переконування або надання допомоги. Об'єктом кримінально-правової охорони є людське життя, а також свобода від деструктивного впливу на те, як потерпілий розпоряджається своїм власним життям.

Особливу увагу приділено способу тлумачення термінів «переконування» та «надання допомоги» як ознак аналізованого складу злочину в доктрині кримінального права. Наголошено, що не кожне переконування та не будь-яке надання допомоги становить собою ознаки складу злочину, передбаченого ст. 151 КК РП. Відповідно до диспозиції цієї норми, об'єктивна сторона може бути вчинена лише за допомогою діянь, які мають настільки сильний вплив на іншу особу, що можуть вважатися такими, що відповідають вимогам «доведення до» спроби самогубства.

Констатовано, що злочин може бути вчинений лише шляхом дії у випадку доведення до самогубства шляхом переконування та в обох фрормах заборонених діянь (шляхом дії та бездіяльності) у випадку надання допомоги у вчиненні самогубства. Склад злочину є матеріальним; його ознаки охоплюють суспільно небезпечні наслідки, які варто розуміти не як смерть потерпілого, а як спроба самогубства, незалежно від того, яким був ії результат. Це є один із злочинів, який може бути вчинений лише умисно (можливі обидва види умислу: dolus directus i dolus eventualis). Покарання за вчинення аналізованого злочину - позбавлення волі на строк від 3 місяців до 5 років.

Ключові слова: самогубство, переконування, надання допомоги, спроба самогубства. 